\title{
ACOUSTIC STRUCTURE OF THE VOICE IN CHILDREN CONSIDERED FOR PARTIAL DEAFNESS TREATMENT
}

\author{
Agata Szkielkowska ${ }^{1,2}$, Joanna Ratynska ${ }^{1,2}$, Henryk Skarzynski ${ }^{1,2}$, Tomasz Michalak ${ }^{1,2}$ \\ ${ }^{1}$ Institute of Physiology and Pathology of Hearing, ul. Zgrupowania AK "Kampinos" 1, 01-943 Warszawa, Poland \\ ${ }^{2}$ World Hearing Center, ul. Mokra 17, Kajetany 05-830 Nadarzyn, Poland
}

Corresponding author: Agata Szkiełkowska, ul. Mokra 17, 05-830 Nadarzyn, Kajetany, Poland,

Phone: +48223560366, e-mail: a.szkielkowska@ifps.org.pl

\begin{abstract}
Background: Partial deafness (PD) is a condition in which normal hearing is preserved in the low frequency range, while severe to profound hearing loss is observed in the middle and high frequency ranges. The aim of this study was to assess the acoustic structure of the voice in children considered for partial deafness treatment (PDT).

Material and methods: The material included 127 children aged from 5 to 12 years old. The study group included children with partial deafness (PD). Depending on age, patients in the study group were divided into 2 groups. The first included 40 children aged 5-6 years, and the second consisted of 44 school-age children aged 7-12 years. The control group included 20 healthy normally hearing children aged 5-6 years and 23 healthy, normally hearing children with clear voices, aged 7-12 years. Children's voices were assessed subjectively by the physician and objectively with the use of a digital CSL KAY Multidimensional Voice Profile analyser (MDVP). The sustained vowel "a” was used for analysis.

Results: Acoustic features of PD vs. normally hearing children were different. Statistically significant parameters differentiating voices in the group of younger children were fundamental frequency (Fo); shimmer, a parameter describing changes in amplitude (ShdB); and noise-to-harmonic-ratio (NHR). In the group of older children more acoustic parameters characterizing voices of PD children were defined. They included fundamental frequency (Fo); fundamental frequency variation (vFo); amplitude change (vAm, sAPQ); noise-to-harmonic-ratio (NHR); and voice tremor (FTRI).
\end{abstract}

Conclusions: The acoustic structure of the voice in children with partial deafness is different from that in children with normal hearing.

Key words: partial deafness treatment $\bullet$ voice $\bullet$ children

\section{ESTRUCTURA ACÚSTICA DE LA VOZ EN LOS NIÑOS CONSIDERADOS PARA EL TRATAMIENTO DE SORDERA PARCIAL}

\section{Resumen}

Antecedentes: La sordera parcial (PD) es una condición en la cual se conserva una audición normal en el rango de frecuencia baja, mientras que se observa pérdida auditiva severa a profunda en los rangos de frecuencia media y alta. El objetivo de este estudio fue evaluar la estructura acústica de la voz en los niños considerados para el tratamiento de la sordera parcial (PDT).

Material y métodos: El material incluyó a 127 niños de edades comprendidas entre 5 y 12 años. El grupo de estudio incluyó a niños con sordera parcial (PD). Dependiendo de la edad, los pacientes del grupo de estudio fueron divididos en 2 grupos. El primero incluyó a 40 niños de 5-6 años, y el segundo contó con 44 niños en edades escolares de 7-12 años. El grupo de control incluyó a 20 niños sanos con audición normal con edades de 5-6 años y 23 niños sanos, con audición normal, con voces claras y edades entre 7-12 años. Las voces de los niños fueron evaluadas subjetivamente por un médico y objetivamente mediante un analizador digital CSL KAY Multidimensional Voice Profile (MDVP). Para el análisis se utilizó la vocal sostenida „a”.

Resultados: Características acústicas de los niños con la PD vs a los con audición normal eran diferentes. Los parámetros estadísticamente significativos que diferencian las voces en el grupo de los niños más pequeños fueron la frecuencia fundamental (Fo); el brillo, un parámetro que describe los cambios en la amplitud (ShdB), y el ratio ruido-armonía (NHR). En el grupo de niños mayores se definieron los parámetros más acústicos que caracterizan voces de los niños con PD. Estos incluyeron la frecuencia fundamental (Fo), la variación de la frecuencia fundamental (vFo), el cambio de amplitud (vAm, sAPQ), el ratio ruido-armonía (NHR), y el temblor de voz (FTRI).

Conclusión: La estructura acústica de la voz en niños con sordera parcial es diferente de la de los niños con audición normal.

Palabras clave: tratamiento de sordera parcial $\bullet$ voz $\bullet$ niños 


\section{LA STRUCTURE ACOUSTIQUE DE LA VOIX CHEZ LES ENFANTS PRIS EN CONSIDÉRATION POUR LE TRAITEMENT DE LA SURDITÉ PARTIELLE}

\section{Résumé}

Contexte: La surdité partielle est un état dans lequel l'audition normale est conservée dans la gamme des basses fréquences, tandis qu'une perte auditive sévère ou profonde est observée dans les gammes de fréquences moyennes et hautes. Le but de cette étude était d'évaluer la structure acoustique de la voix chez les enfants pris en considération pour le traitement de la surdité partielle.

Matériel et méthodes: Le groupe d'étude se composait de 127 enfants agés de 5 à 12 ans. Ce groupe comprenait des enfants touchés de surdité partielle. Selon leur âge, les patients du groupe d'étude étaient divisés en 2 groupes. Le premier comprenait 40 enfants agés de 5-6 ans, et le second était composé de 44 enfants en âge scolaire, agés de 7-12 ans. Le groupe de contrôle comportait 20 enfants sains, avec une audition normale, agés de 5-6 ans et 23 enfants sains, avec une audition normale et des voix claires, agés de 7-12 ans. Les voix des enfants étaient évaluées de manière subjective par le médecin, et de manière objective, par analyse multidimensionnelle du programme de voix, à l'aide du spectographe numérique CSL KAY.

Résultats: Les caractéristiques acoustiques des enfants avec surdité partielle étaient différentes de celles des enfants qui entendaient normalement. Les paramètres statistiquement significatifs différenciant les voix dans le groupe des plus jeunes enfants étaient: la fréquence fondamentale (Fo), le paramètre décrivant l'évolution de l'amplitude (SHDB), et le bruit à-harmoniques ratio (NHR). Dans le groupe d'enfants plus âgés, un plus grand nombre de paramètres acoustiques caractérisant les voix des enfants touchés de surdité partielle ont été définis. Ils comprenaient la fréquence fondamentale (Fo), la variation de la fréquence fondamentale (VFO), le changement d'amplitude (vAm,sAPQ); le bruit-à-harmoniques ratio (NHR), et le chevrotement (FTRI).

Conclusions: La structure acoustique de la voix chez les enfants atteints de surdité partielle est différente de celle présente chez les enfants ayant une audition normale.

Mots clés: traitement de la surdité partielle $\bullet$ voix $\bullet$ enfants

\section{АКУСТИЧЕСКИЕ ХАРАКТЕРИСТИКИ ГОЛОСА У ДЕТЕЙ С ПОКАЗАНИЯМИ К ЛЕЧЕНИЮ ЧАСТИЧНОЙ ГЛУХОТЫ}

\section{Краткий обзор}

История вопроса: Частичная глухота (PD) - состояние, при котором нормальная острота слуха сохраняется в диапазоне низких частот, при потере слуха с выраженностью от сильной до углубленной, наблюдаемой в диапазоне средних и высоких частот. Целью данного исследования было определить акустические характеристики голоса детей с показаниями к лечению частичной глухоты (PDT).

Материалы и методы: В исследовании принимали участие 127 детей в возрасте от 5 до 12 лет. Опытная группа включала детей с частичной глухотой (PD). В зависимости от возраста, пациенты в составе опытной группы были разделены на 2 подгруппы. Первая подгруппа была образована 40 детьми в возрасте 5-6 лет, вторая состояла из 44 детей школьного возраста, а именно 7-12 лет. В контрольную группу было набрано 20 здоровых детей без нарушений слуха возрастом 5-6 лет и 23 здоровых ребенка без нарушений слуха и со звонким голосом возрастом 7-12 лет. Характер голоса детей подлежал субъективной оценке врача и объективной оценке при помощи цифрового многоразмерного анализатора голосового профиля CSL KAY (MDVP). Анализ проводили с помощью растянутой гласной «а».

Результаты: Акустические характеристики у детей с PD относительно детей с нормальным слухом различались. Статистически достоверными параметрами, позволявшими провести различие между голосами в группе детей младшего возраста, были основная частота (Fo); дрожь голоса - параметр, описывающий изменения амплитуды (ShdB) и соотношение шум/гармоники (NHR). B группе детей старшего возраста было определено большее число параметров, характеризующих голоса детей с PD. Такие параметры включали основную частоту (Fo); вариации основной частоты (vFo); изменения амплитуды (vAm, sAPQ); соотношение шум/гармоники (NHR); и тремор голоса (FTRI).

Заключение: Акустические характеристики голоса детей с частичной глухотой отличаются от таковых у детей с нормальной остротой слуха.

Ключевые слова: лечение частичной глухоты • голос • дети 


\section{Background}

Hearing loss acquired at any phase of life results in development of a specific voice disorder called audiogenic dysphonia. Dysphonia is a term describing voice disorder involving any acoustic voice component, such as frequency, intensity, duration, and timbre. The mode of voice production, its characteristics, pitch, and phonation time are changed in subjects with audiogenic dysphonia [8].

Lack of proper auditory feedback in hearing-impaired subjects results in functional voice disorder. It is directly related to discoordination of intrinsic and extrinsic laryngeal muscles, and disturbed contraction and relaxation of antagonistic muscles. The voice organ of a hearing impaired child shows no anatomical abnormalities in the first years of life, provided that the factor that caused the hearing disorder did not affect the larynx. Data in the literature suggest that the impairment of the voice organ is a secondary effect and results not only from abnormal auditory feedback but also from inappropriate hearing, voice, and speech rehabilitation in early childhood, or even its cessation $[1,3,8]$.

Research on the physiopathology of voice and speech in hearing-impaired children proves that a physiological deficiency of the larynx affects phonation and articulation. Specialists therefore emphasise that voice and speech rehabilitation should begin as soon as possible, helping to maintain correct functioning of the larynx $[9,18]$. Changes in the larynx of a prelingually hearing-impaired child and changes in his/her voice develop in the first years of life. The nature of these disorders depends on numerous conditions, including degree and type of hearing loss, duration of the hearing impairment, the moment of its occurrence, the treatment applied and benefits obtained, as well as the effectiveness of wide-range rehabilitation and other environmental factors.

Limited functioning of the patient's ear impairs their voice control and may have a negative effect on their communication. Auditory disorders prevent the patients from regulating the pitch, intensity, rhythm, and timbre of their voice. In hearing-impaired children, the melody of their voice remains at a low level because the inborn, primary reflexes cannot develop further. Development of the acoustic structure of their voice ceases when hearing impairment occurs. Normally, over time the vocal range becomes extended and the voice gets lower because of the development of the phonatory-articulation apparatus. But disablement of auditory feedback and control of speech prevents the formation of a normal voice and phonation. One of the specific features of audiogenic dysphonia, apart from monotony, is pitch variation $[1,11,13]$. The voice clearly changes its timbre.

Length of utterance time increases proportionally to the degree of hearing impairment. While the voice range of a hearing-impaired child fails to extend, the phonation time also reduces. Hearing-impaired children may demonstrate significant disorders of respiratory-phonation coordination, characterized by a shortened exhaling phase and a frequent and too deep inhaling phase, the result of which is dissynchronization of exhalation, phonation, and articulation. One of the most common disorders observed in the hearing impaired is a laryngeal hyperfunction with visible spasticity of face and neck muscles. The voice of such patients has been described as husky, dull, hoarse, wavy, screaming, nasal, pushy, harsh, and intense [17]. Often the pharyngeal constrictor is too weak to separate the middle part of the throat from the upper throat and nasal cavity. As a result, air passes through the nose during speech, producing nasal sounds.

Partial deafness (PD) is a condition in which normal hearing is preserved in the low frequency range, while severe to profound hearing loss is observed in the middle and high frequency ranges $[14,15]$. Such a condition gives limited possibilities for perceiving, differentiating, and identifying speech sounds. However it does allow for voice and verbal communication development. In some cases of $\mathrm{PD}$, voice disorder is not detectable but speech reception problems are clearly visible - problems with understanding speech and identifying directed messages. While it is important to perceive and understand verbal stimuli, in the wider context of interpersonal communication sound production is equally important. Voice is the medium for oral speech, and so its disorder impacts the quality of verbally created messages and disturbs the communication process.

Data in the literature suggest that the acoustic structure of the voice of hearing-impaired children differs depending on age $[16,17,19]$. The acoustic structure of the voice of normally hearing children changes with their growth and development, whereas in hearing-impaired children, apart from changes in the fundamental frequency, Fo, it does not significantly change and its development is delayed $[1,2,8,18]$.

The aim of this study was to assess the acoustic structure of voice in children considered for PDT.

\section{Material and methods}

The material included 127 children aged from 5 to 12 years old. The study group were children diagnosed with sensorineural hearing loss over $1000 \mathrm{~Hz}$ - which is defined as partial deafness (PD). All were patients of the Institute of Physiology and Pathology of Hearing. Depending on age, the patients in the study group were divided into 2 groups. The first included 40 children aged 5-6 years and the second consisted of 44 school-age children aged 7-12 years. The control group included 20 healthy normally hearing children aged 5-6 years and 23 healthy, normally hearing children with clear voices, aged 7-12 years. The research group was selected according to the uniform characteristics of the hearing loss and the type of audiogram (Figure 1).

All children underwent phoniatric and laryngological examinations as well as subjective and objective voice assessment. The examinations excluded possible pathologies (palate dysplasias, cleft palate, mental deficiency, asthma, craniofacial congenital defects) that could influence the quality of voice and phonation in the larynx. All underwent hearing tests, and middle ear function was assessed by tympanometry and stapedius reflex measurements. Hearing thresholds were assessed in an age-appropriate manner: for cooperative children pure tone audiometry was performed; 

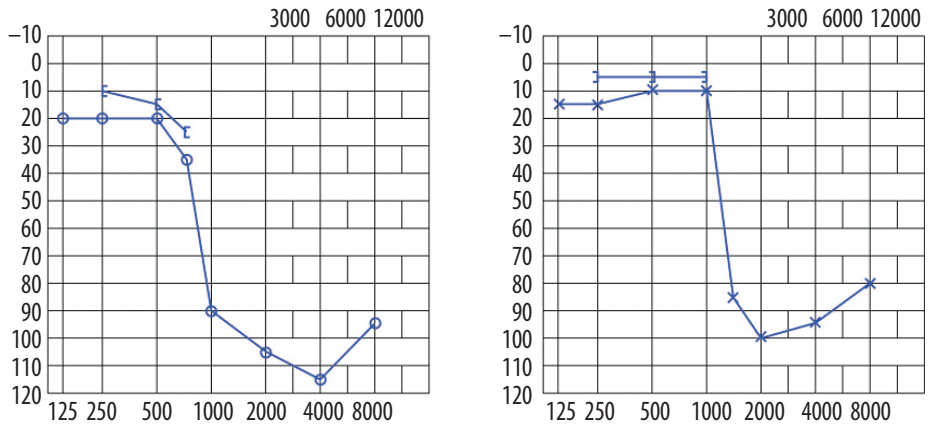

Figure 1. Typical audiograms from a PD case aged 11 y.o.The left panel shows the threshold levels from the right ear, the right panel shows the threshold levels of the left ear. Brackets in both charts show bone conduction levels.

in non-cooperating cases, wave $\mathrm{V}$ thresholds were obtained by ABR examination. Voice was assessed subjectively considering the following features: character, production mode, type of voice attack, and intensity. Objective measurements included digital voice recording of all patients using a condenser microphone under studio conditions.

Each patient had to produce a prolonged "a" vowel with their lips $10 \mathrm{~cm}$ from the microphone. Acoustic analysis was done using a CSL 4300B KAY digital measurement interface (Multidimensional Voice Profile, MDVP). Selected fragments of the prolonged vowel were analysed in each case. Parameters assessed in the MDVP program consist of groups describing physical properties of voice. They include parameters describing short and long-term frequency perturbation (Jitt, Jita, RAP, PPQ, sPPQ, vFo), parameters assessing short and long-term amplitude perturbations (Shim, ShdB, APQ, sAPQ, vAm), noise-related parameters (NHR, VTI, SPI), tremor-related parameters (FTRI, ATRI), voice breaks (DVB), degree of subharmonics (DSH), and voice irregularity (DUV). For the purpose of the study, 17 parameters which show the greatest clinical importance have been analyzed (Table 1).

Our results document and give a graphical view of the children's voices. Statistical analysis of the results was performed using an Anova test and post-hoc U-test. Statistical significance was set at $p<0.05$. All children were assessed for partial deafness treatment with a cochlear implant.

\section{Results}

Speech assessment revealed that all children in the research group had developed verbal communication. All patients were attending kindergartens or mainstream schools.

During the assessment children did not use hearing aids. Mostly they used grammatically correct speech. Articulation disorders were observed in 55 of the children $(65 \%)$, and in 25 (30\%) speech was not fluent; 26 children (31\%) had problems in understanding complex commands. Subjective voice assessment revealed that in 55 cases (65\%) voices were abnormal. Voices were dull, unstable, too high, harsh, or of high volume. Subjective voice assessment by a physician appeared less informative than objective examination. Objective assessment revealed harmonic irregularities of voices in all cases.

Results obtained by MDVP analysis showed that the voices of partially deaf children differ in most of the acoustic parameters from voices of normally hearing children (Table 1).

In the research group we observed differences, compared to the control group, in parameters describing disturbances of frequency, amplitude, and voice tremor, and in parameters showing the presence of noise elements. Acoustic analysis allowed us to select statistically significant acoustic parameters that differentiated both age groups from the control groups. Statistically significant parameters differentiating voices in the group of younger children were fundamental frequency (Fo); shimmer, a parameter describing changes in amplitude (ShdB), and noise-to-harmonic-ratio (NHR). The mean value of the fundamental frequency Fo in the group of younger children was $293 \mathrm{~Hz}$, higher than the control group where the mean value was 270 $\mathrm{Hz}$; ShdB and NHR were significantly lower than in normally hearing children.

In the group of older children, a larger number of acoustic parameters characterizing voices of PD children were found. They included fundamental frequency (Fo), fundamental frequency variation ( $\mathrm{vFo}$ ), amplitude change (vAm, sAPQ), noise-to-harmonic-ratio (NHR), and voice tremor (FTRI). The fundamental frequency Fo in the group of children considered for PDT was $240 \mathrm{~Hz}$, whereas in the age-matched group of hearing children it was $217 \mathrm{~Hz}$. The fundamental frequency variation $(\mathrm{vFo})$ in the group of partially deaf older children was lower than in the control group. The parameter describing amplitude change, sAPQ, was significantly lower in the partially deaf older children compared to the normally hearing children. The peak amplitude variation (vAm) was considerably elevated in the examined group. Among the noise components (NHR, VTI, SPI), significant differences were observed in the soft phonation index (SPI) and noise-to-harmonicratio (NHR), which were much lower than in the control group. In the group of older PD children, the voice tremor index (FTRI) was 0.34 , lower than in controls.

\section{Discussion}

Our results show that the acoustic structure of the voices of partially deaf children differs significantly from the structure of voices of normally hearing children in several features. Disturbances of frequency, amplitude, tremor, and noise were observed in the examination group. Similar tendencies have been observed in deaf children and in children with sensorineural hearing loss of a different 
Table 1. Acoustic voice parameters in younger and older PD children and control groups.

\begin{tabular}{|c|c|c|c|c|}
\hline Parameters & Control group & PD 5-6 y.o. & Control group & PD 7-12 y.o. \\
\hline FO & $270 \mathrm{~Hz}$ & $293 \mathrm{~Hz}^{*}$ & $217 \mathrm{~Hz}$ & $240 \mathrm{~Hz}^{*}$ \\
\hline Jita & $112 \mu \mathrm{s}$ & $68.9 \mu \mathrm{s}$ & $77.66 \mu \mathrm{s}$ & $41.06 \mu \mathrm{s}$ \\
\hline Jitt & $2.83 \%$ & $2.01 \%$ & $1.64 \%$ & $1.12 \%$ \\
\hline RAP & $1.7 \%$ & $1.2 \%$ & $0.99 \%$ & $0.66 \%$ \\
\hline PPQ & $1.7 \%$ & $1.2 \%$ & $1.00 \%$ & $0.62 \%$ \\
\hline SPPQ & $2.07 \%$ & $1.8 \%$ & $1.44 \%$ & $0.95 \%$ \\
\hline vFO & $6.77 \%$ & $6.87 \%$ & $5.13 \%$ & $4.12 \%{ }^{\star}$ \\
\hline ShdB & $0.81 \mathrm{~dB}$ & $0.49 \mathrm{~dB}^{\star}$ & $0.55 \mathrm{~dB}$ & $0.38 \mathrm{~dB}$ \\
\hline Shim & $8.65 \%$ & $5.36 \%$ & $6.18 \%$ & $4.96 \%$ \\
\hline APQ & $6.35 \%$ & $4.11 \% *$ & $4.55 \%$ & $3.60 \%$ \\
\hline SAPQ & $8.79 \%$ & $6.65 \%$ & $7.05 \%$ & $6.24 \% *$ \\
\hline vAm & $20.25 \%$ & $22.16 \%$ & $14.71 \%$ & $20.96 \% *$ \\
\hline $\mathrm{NHR}$ & 0.23 & $0.15^{\star}$ & 0.17 & $0.15^{\star}$ \\
\hline VTI & 0.08 & 0.07 & 0.05 & 0.05 \\
\hline SPI & 4.27 & 7.41 & 9.43 & $6.99^{*}$ \\
\hline FTARI & 1.29 & 0.55 & 0.78 & $0.34^{*}$ \\
\hline ATRI & $7.49 \%$ & $5.68 \%$ & $3.86 \%$ & $4.0 \%$ \\
\hline
\end{tabular}

* Statistically significant differences between studied and control groups.

type. Results presented here indicate voice disorders and other abnormalities in PD children, although compared to deaf children and children using hearing aids, as found by other authors $[7,8,11,13]$, they are much better.

It is worth pointing out that all examined children composed sentences freely and did not show significant voice disorders during assessment. This is a major difference compared to children suffering from other types of hearing disorders. Partial deafness is a type of hearing loss that limits sound perception, differentiation, and identification, but it does allow voice development and verbal communication.

In the presented material, school-age children were observed to have more abnormalities in the acoustic structure of their voices than the younger children. This may be connected with an increased demand on hearing function when children start school. Acoustic features of the voice change with age, which is why voices were compared in age-matching groups.

Data in the literature suggest that by examining the acoustic properties of the voice it is possible to obtain information on the subjective quality of the produced voice and the phonatory function of the larynx $[1,2,5]$. Voice is an acoustic phenomenon and all its disorders are characterized by abnormal values of its components - frequency, amplitude, intensity, duration, and timbre $[8,19]$. Acoustic measurements are useful for assessing the voice of hearingimpaired children, including children with partial deafness.
Acoustic analysis of the voice is a valuable complement to a basic phoniatric examination and perceptual voice assessment $[4,8]$. Data in the literature show that after cochlear implantation there is significant improvement in the acoustic structure of the voice in children with profound sensorineural hearing loss $[4,5,8,10-13]$. Authors are in agreement that rehabilitation greatly affects voice development in children with hearing disorders [6,17]. Our analysis confirms that cochlear implantation in partially deaf children can restore hearing in the lost high frequencies, allowing development of auditory feedback control of speech and proper voice development $[14,15]$.

Data in the literature suggest the important role of acoustic examinations in rehabilitation programs for hearingimpaired children [18]. Rehabilitation in hearing-impaired children does not differ from the common practice of voice rehabilitation. Nonetheless, a rehabilitation program should be individually adjusted to the patient's age, language skills, intellectual abilities, general health, and emotional profile [17]. Rehabilitation should always be based on trust between the patient and the therapist.

Since voice rehabilitation is closely connected with effective auditory ability, it is easy to imagine how difficult it is to introduce exercises to improve the voice in patients who have partially lost their hearing. The objective of voice therapy is to achieve auditory differentiation and feedback. If hearing abilities are lacking in cases of hearing-impaired patients, then vision and touch can be used as additional channels of contact. Children especially need to observe 
and perform mimicking exercises with numerous repetitions, even though it is often difficult for them to verify their own voice and speech because of diminished auditory feedback. An impaired hearing-voice-speech loop makes it nearly impossible to produce correct or almost correct phonation patterns.

In such cases we often observe excessive mobilisation of the whole muscle apparatus, including respiratory muscles and pharyngeal and articulation muscles. Speech therapists and phoniatricians must be aware that inappropriate auditory feedback control, or its incorrect use during rehabilitation, may lead to development and establishment of wrong phonatory habits which can affect the quality of the produced voice. This is why auditory training is so important.

The most difficult phase during voice rehabilitation of hearing-impaired patients is teaching them to identify correct and incorrect features of the voice. Thus, the first phase of rehabilitation should be educational and should provide knowledge of voice features, differences resulting from various ways of producing it, and general awareness of the processes involved. Such an education is very difficult, considering that a partially deaf child is often disoriented and lost, not only during conversation but also in play with other children. The child is perceived as such by the people around them and as a consequence develops a whole variety of inappropriate emotions and attitudes (frustration, lack of confidence, alienation).

Voice plays an important role in expressing the emotional state of a person. It reflects our emotional condition, and our emotions impact the way it is produced and its quality. Emotions affect muscle tension in the vocal folds and the whole vocal tract, the larynx position, and the larynx's readiness to produce sounds. In positive situations, when we are joyful, the reactions connected with voice production are optimal. Negative emotions, such as anger, cause muscle tension in all the structures engaged in producing the voice and convey this information.

To sum up, children with PD present disorders in acoustic voice structure, although the limited stage of the disorder still makes it possible to communicate. In cases of children with high-frequency hearing loss causing partial deafness, cochlear implantation and subsequent rehabilitation offer a chance to improve the acoustic structure of the voice and of communication in general.

\section{Conclusions}

Results obtained during research on children considered for PDT allow us to conclude that:

1. The acoustic structure of the voice in children with partial deafness is different to that in children with normal hearing.

2. More significant disorders of acoustic voice structure were observed in school children, which may be due to a bigger need for hearing function during the learning period.

3. Acoustic analysis of the voice may serve as a sensitive indicator of hearing improvement in PD children after cochlear implant treatment.

\section{References:}

1. Chouard $\mathrm{CH}$ : Changes on the speaking fundamental frequency after cochlear implantation. Ann Otolaryng Cir Cevicofac 1988; 105(4): 249-52

2. Giusti Maria C: The hearing-impaired children voice. E.N.T. Brazilian Society Official Publication, 2001; 67(1)

3. Kirk KI: Speech and language results in children with a cochlear implant. Ear \& Hearing, 1985; 6(Suppl.3): 368-478

4. Kirk KI et al: The effects of cochlear implant use on voice parameters, Otolaryng. ClinNorth Am, 1983; 16(1): 281-92

5. Kotby MN et al: Multidimensional analysis of speech of hearing impaired children. Scand Audiol Suppl, 1996; 42: 27-33

6. Lamprecht A: Phoniatric aspects in rehabilitation of patients with cochlear implants., LaryngolRhinolOtol (Stuttg), 1986; 65(8): 445-49

7. Leder SB: Immediate effects of cochlear implantation on voice quality. Arch Otolaryng, 1987; 244(2): 93-95

8. Maniecka-Aleksandrowicz B et al: Zaburzenia głosu i rehabilitacja osób z uszkodzonym narządem słuchu., Wydawnictwo DiG Warszawa, 1998

9. Manning WH et al: Vowel production in a prelinguistic child following cochlear implantation. J Am Acad Audiol, 1992; 3(1): $16-21$

10. Oster AM: Some effects of cochlear implantation on speech production. Proceeding X Congress ICPhS Tallin, 1987; 4: $177-80$
11. Perrin E et al: Evaluation of cochlear implanted children's voices. J Pediatr Otorhinolaryngol, 1999; 47(2): 181-86

12. Perrin ME, Berger-Vachon $C$, Le Dissez $C$ et al: The normality of voice of cochlear implant children. Oto-Rhino-Laryngology, 1995; (50): 167

13. Pruszewicz A et al: Varability analysis of Fo parameter in voice of individuals with hearing disturbances. Acta Otolaryng (Stockh.), 1993; 113: 450-54

14. Skarzynski H, Lorens A, Piotrowska A, Skarzynski PH: Hearing preservation in partial deafness treatment. Med Sci Monit, 2010; 16(11): CR555-62

15. Skarzynski H, Lorens A, Piotrowska A: A new method of partial deafness treatment. Med Sci Monit, 2003; 9(4): CS20-24

16. Skrypnik I,Grzanka A,Puuronen S, Szkiełkowska A: Selection of Voice Features to Diagnose Hearing Impairments of Children. IEEE CS Press, 2001; 427-32

17. Szkielkowska A: Rehabilitacja glosu dzieci z implantami slimakowymi. Audiofonologia, 1999; XV: 133-41

18. Szkielkowska A, Maniecka-Aleksandrowicz B, Dolecki J: Voice rehabilitation in children post cochlear implantation. Central and East Europen Journal of Oto-Rino-Laryngology Head and Neck Surgery, 2000; 1(14)

19. Whiteside SP: Acoustic characteristics in 6-10-year old children's voices: some preliminary findings. Logoped Phoniatr Vocol, 1999; 24(1): 6-12 